\title{
The scavenging capacity of DMBT1 is impaired by germline deletions
}

\author{
Floris J. Bikker ${ }^{1}$ - Caroline End ${ }^{2}$ • Antoon J. M. Ligtenberg ${ }^{1} \cdot$ Stephanie Blaich $^{2}$ • \\ Stefan Lyer ${ }^{2} \cdot$ Marcus Renner ${ }^{2} \cdot$ Rainer Wittig $^{2} \cdot$ Kamran Nazmi $^{1}$. \\ Arie van Nieuw Amerongen ${ }^{1}$ - Annemarie Poustka ${ }^{2}$ - Enno C.I. Veerman ${ }^{1}$. \\ Jan Mollenhauer ${ }^{2,3}$
}

Received: 20 December 2016/Accepted: 27 March 2017 /Published online: 31 March 2017

(C) The Author(s) 2017. This article is published with open access at Springerlink.com

\begin{abstract}
The Scavenger Receptor Cysteine-Rich (SRCR) proteins are an archaic group of proteins characterized by the presence of multiple SRCR domains. They are membrane-bound or secreted proteins, which are generally related to host defense systems in animals. Deleted in Malignant Brain Tumors 1 (DMBT1) is a SRCR protein which is secreted in mucosal fluids and involved in host defense by pathogen binding by its SRCR domains. Genetic polymorphism within DMBT1 leads to DMBT1-alleles giving rise to polypeptides with interindividually different numbers of SRCR domains, ranging from 8 SRCR domains (encoded by $6 \mathrm{~kb} D M B T 1$ variant) to 13 SRCR domains (encoded by the $8 \mathrm{~kb} D M B T 1$ variant). In the present study, we have investigated whether reduction from 13 to 8 aminoterminal SRCR domains leads to reduction of bacterial binding. The $6 \mathrm{~kb}$ variant bound $\sim 20-45 \%$ less bacteria compared to the $8 \mathrm{~kb}$ variant. These results support the hypothesis that genetic variation in DMBT1 may influence microbial defense.
\end{abstract}

Keywords SRCR domain - Genetic polymorphism . Pathogen binding $\cdot$ Microbial defense

Floris J. Bikker

fbikker@acta.nl

1 Department of Oral Biochemistry, Academic Centre for Dentistry Amsterdam, University of Amsterdam and VU University Amsterdam, Gustav Mahlerlaan 3004,

1081LA Amsterdam, Netherlands

2 Division of Molecular Genome Analysis, German Cancer Research Center, Heidelberg, Germany

3 Molecular Oncology, University of Southern Denmark, Odense, Denmark

\section{Introduction}

The Scavenger Receptor Cysteine-Rich (SRCR) proteins are an archaic group of highly conserved proteins in animals (Aruffo et al. 1997; Freeman et al. 1990; Muller et al. 1999; Pahler et al. 1998; Resnick et al. 1994). The SRCR-superfamily is comprised of cell membrane-anchored proteins as well as secretory proteins. SRCR proteins are characterized by the presence of multiple SRCR domains. SRCR domains are approximately 110 amino acids long and are classified into groups $\mathrm{A}$ and $\mathrm{B}$ based on the number of conserved cysteine residues (six for group A, eight for group B) (Aruffo et al. 1997; Resnick et al. 1994). Generally, SRCR proteins, e.g., the macrophage scavenger receptor, Mac2binding protein, $\mathrm{CD} 5, \mathrm{CD} 6$, and $\mathrm{WC1}$, have generally been implicated into host defense systems (Aruffo et al. 1997; Aruffo et al. 1991; Elomaa et al. 1998; Freeman et al. 1990; Gough and Gordon 2000; Holmskov et al. 1999; Ligtenberg et al. 2001; Prakobphol et al. 2000; Tino and Wright 1999).

Deleted in Malignant Brain Tumors 1 (DMBT1) at chromosome 10q25.3-q26.1 is a member of the group B SRCR superfamily (Holmskov et al. 1997; Holmskov et al. 1999; Ligtenberg et al. 2001; Mollenhauer et al. 1997; Prakobphol et al. 2000). DMBT1 is composed of 13 highly homologous SRCR domains (Aruffo et al. 1997; Hohenester et al. 1999), separated by SRCR-interspersed domains (SIDs), two CUB (C1r/C1s Uegf Bmp1) domains (Bork and Beckmann 1993; Romero et al. 1997), separated by a 14th SRCR domain, and a Zona Pellucida domain (Jovine et al. 2002; Sinowatz et al. 2001). DMBT1 is expressed in saliva (DMBT1 ${ }^{\text {SAG }}$ ) and other mucosal fluids along the gastro-intestinal tract, in the lungs $\left(\mathrm{DMBT}^{\mathrm{GP} 340}\right.$ ), and amniotic fluid (Holmskov et al. 1997; Holmskov et al. 1999; Ligtenberg et al. 2004; Mollenhauer et al. 1997; Prakobphol et al. 2000; Reichhardt et al. 2014). In saliva, the concentration of DMBT1 ${ }^{\mathrm{SAG}}$ is approximately $20 \mu \mathrm{g} / \mathrm{ml}$ (Sonesson et al. 2011). DMBT1 plays various roles 
in innate immunity, e.g., by activating the MBL-mediated lectin pathway of the complement system (Gunput 2016); it binds to surfactant proteins A and D (Holmskov et al. 1997; Tino and Wright 1999), IgA (Ligtenberg et al. 2004), MUC5B (Thornton et al. 2001), C-type lectin receptors DC-SIGN and Langerin (Boks et al. 2016), influenza virus and HIV (Hartshorn et al. 2003; Stoddard et al. 2007), the dental hard tissue (Bikker et al. 2013), and a wide spectrum of bacteria (Bikker et al. 2004; Bikker et al. 2002; Leito et al. 2008; Madsen et al. 2010). In particular, the SRCR/SID region in DMBT1 appears to play a dominant role in bacterial binding (Bikker et al. 2004; Bikker et al. 2002; Brittan and Nobbs 2015; Kukita et al. 2013).

We have unraveled genetic polymorphism within DMBT1 (Mollenhauer et al. 1999; Mollenhauer et al. 2002b). This results in DMBT1 alleles encoding polypeptides that have different numbers of SRCR domains within the SRCR/SID region, ranging from 8 to 13 . This SRCR/SID region does not include the carboxy-terminal SRCR domain, which is located in between the CUB domains. This 14th SRCR domain does not show bacterial-binding activity (Holmskov et al. 1997). Based on analogies to mucins, we postulate that these polymorphisms may lead to a differential efficacy in mucosal protection (Kohlgraf et al. 2003; Mollenhauer et al. 2001; Mollenhauer et al. 2000; Polley et al. 2015).

In the present study, we have selected individuals homozygous for either 8 or 13 SRCR domains and showed a corresponding reduction of the protein size of $\mathrm{DMBT} 1^{\mathrm{SAG}}$. We consistently observed that, compared to wild-type DMBT1 ( $8 \mathrm{~kb}, 13$ SRCR domains in the SID/SRCR region), the short DMBT1variant $(6 \mathrm{~kb}, 8$ SRCR domains in the SID/SRCR region) displayed $30-45 \%$ reduced capacity in binding to bacteria in vitro.

\section{Materials and methods}

\section{Southern blotting}

Genomic DNA from healthy volunteers (ethnic background: Caucasian) was extracted from peripheral blood leukocytes (PBL) according to standard procedures. Collection of blood samples and genetic analyses were approved by the ethics committee of the University of Heidelberg. Twentymicrogram of genomic DNA was digested overnight with the restriction enzyme RsaI (Roche Diagnostics; $10 \mathrm{U} / \mu \mathrm{g}$ DNA), ethanol-precipitated, and resuspended in a total volume of $40 \mu \mathrm{H}_{2} \mathrm{O}$. The digested DNA was separated for $20-22 \mathrm{~h}$ on $1.2 \%(w / v)$ agarose gels at $45 \mathrm{~V}$. From this point on, everything was exactly done as described previously (Mollenhauer et al. 1999), with the exception that exclusively probe DMBT1/ sr1sid2 was used.

\section{Bacteria}

Streptococcus mutans (Ingbritt), Streptococcus gordonii (HG222) and Escherichia coli (F7) were cultured on blood agar plates under anaerobic conditions with $5 \% \mathrm{CO}_{2}$ at $37^{\circ} \mathrm{C}$ for $24 \mathrm{~h}$. Subsequently, single colonies were cultured in Todd Hewitt medium and in Luria Broth (Oxoid, Hampshire, United Kingdom) for S. mutans, S. gordonii, and E. coli, respectively, overnight in air/ $/ \mathrm{CO}_{2}$ (19:1), at $37^{\circ} \mathrm{C}$. Cells were harvested and washed twice in TTC buffer (TBS-Tween-Calcium buffer: TBS, $150 \mathrm{mM}$ $\mathrm{NaCl}, 10 \mathrm{mM}$ Tris-HCl, pH 7.4; 0.01\% (v/v) Tween 20 (polysorbate, Merck-Schuchardt, Germany); $1 \mathrm{mM}$ calcium). Helicobacter pylori (NCTC 11637) was cultured on selective Dent plates (Oxoid) at $37{ }^{\circ} \mathrm{C}$ for $72 \mathrm{~h}$. H. pylori was harvested by wiping off the plates and washed twice in NTC buffer (100 mM Sodium acetate, $\mathrm{pH} 4.2,0.01 \%(v / \mathrm{v})$ Tween 20, supplemented with $1 \mathrm{mM}$ calcium). Bacteria were diluted in buffer to a final $\mathrm{OD}_{700}$ of 0.5 , corresponding with approximately $5 \times 10^{8}$ cells $/ \mathrm{ml}$.

\section{Collection of DMBT1 ${ }^{\mathrm{SAG}}$ and determination of relative concentration}

Human parotid saliva was collected from healthy donors with a Lashley cup, under stimulation by chewing on sugar-free chewing gum. Collection and use of saliva was approved by the ethics committee of the University of Heidelberg. Twentyfive milliliters of parotid saliva was kept on ice water for $30 \mathrm{~min}$, to promote the formation of a precipitate. This precipitate was collected by centrifugation at $5000 \mathrm{xg}$ at $4{ }^{\circ} \mathrm{C}$ for $20 \mathrm{~min}$. The resulting pellet was dissolved in $2.5 \mathrm{ml}$ TBS. The pellet was approximately tenfold enriched in DMBT1 1 SAG $(\sim 200 \mu \mathrm{g} / \mathrm{ml})$, designated as crude DMBT1 ${ }^{\text {SAG }}$.

For qualitative adhesion assays with $\mathrm{DMBT1}{ }^{\mathrm{SAG}}$, crude $\mathrm{DMBT1}^{\mathrm{SAG}}$ samples from saliva donors (A and B) were titrated against monoclonal antibody (mAb) DMBT1h12. The antibody recognizes a non-repetitive, non SRCR domain, peptide epitope (amino acid 26-40), which is present within all known DMBT1 variants and locates outside the region that shows germline deletions (Fig. 2a) (Stoddard et al. 2007). High affinity microtiter plates (Greiner-F, Polysorp, Nunc, Kamstrup, Denmark) were coated with crude DMBT1 ${ }^{\text {SAG }}$, in coating buffer (100 mM sodium carbonate, $\mathrm{pH}$ 9.6) for $2 \mathrm{~h}$ at $37^{\circ} \mathrm{C}$. This incubation and all the following steps were carried out in a volume of $100 \mu \mathrm{l}$ per well at room temperature, and all washes and incubations were carried out in TTC Buffer. Plates were incubated for $1 \mathrm{~h}$ with 1:500 mAb DMBT1h12. After washing, the plates were incubated at $37{ }^{\circ} \mathrm{C}$ for $1 \mathrm{~h}$ with a rabbit anti-mouse IgG-HRP conjugate (dilution 1:2000 in TTC; DAKO A/S, Denmark). Subsequent to three washes with TTC, $100 \mu \mathrm{l}$ TMB-solution $\left(3,3^{\prime}, 5,5^{\prime}\right.$ Tetramethyl-benzidine; $125 \mu \mathrm{g} / \mathrm{ml}$ in citrate buffer $\mathrm{pH} 4.5$ with $0.05 \% v / \mathrm{v} \mathrm{H}_{2} \mathrm{O}_{2}$ ) was added, and after incubation at RT 
for 10-15 $\mathrm{min}$, the reaction was stopped by the addition of $50 \mu 12 \mathrm{M}$ sulphuric acid per well. The absorbance was read at $405 \mathrm{~nm}$ on a Dynatech MR7000 plate reader (Billington, UK). The results of the ELISA were used to dilute the different DMBT1 ${ }^{\text {SAG }}$ samples to obtain solutions containing comparable concentrations of the unique DMBT1 epitope, which is not the SRCR-epitope. For the adhesion assay, these equalized DMBT1 ${ }^{\text {SAG }}$ solutions were coated onto microtiterplates.

\section{Adhesion assays}

Bacterial adhesion was examined using a microtiter plate method based on labeling of microorganisms with cell-permeable DNA-binding probes (Bikker et al. 2004; Bikker et al. 2002). Microtiterplates Fluotrac 600 (Greiner, Recklinghausen, Germany) were coated with equal amounts of crude SAG from donors $\mathrm{A}$ and $\mathrm{B}$. For this, the samples were dissolved in coating buffer (100 mM sodium carbonate, $\mathrm{pH}$ 9.6) and diluted serially. Bovine Serum Albumin (BSA, Sigma-Aldrich, Zwijndrecht, the Netherlands), coated from 1 to $0.01 \%$, was used a control. This experiment was conducted after the adhesion experiments using DMBT1 $1^{\mathrm{SAG}}$. After incubation at $4{ }^{\circ} \mathrm{C}$ for $16 \mathrm{~h}$, plates were washed twice with TTC. In case of $H$. pylori, plates were washed with NTC. Subsequently, $100 \mu$ l of a bacterial suspension $\left(5 \times 10^{8}\right.$ bacteria $\left./ \mathrm{ml}\right)$ were added to each well and incubated for $2 \mathrm{~h}$ at $37{ }^{\circ} \mathrm{C}$. Plates were washed three times with TTC, or NTC for $H$. pylori, using a plate washer (Mikrotek EL 403, Winooski, VT). Bound bacteria were detected using $100 \mu \mathrm{l} /$ well of $1 \mathrm{mM}$ SYTO-9 solution (Molecular Probes, Leiden, The Netherlands), a cell-permeable fluorescent DNA-binding probe. Plates were incubated in the dark for $15 \mathrm{~min}$ at ambient temperature and washed three times with $0.1 \%$ Tween 20 . Fluorescence was measured in a fluorescence microtiter plate reader (Fluostar Galaxy, BMG Laboratories, Offenburg, Germany) at $488 \mathrm{~nm}$ excitation and $509 \mathrm{~nm}$ emission wavelength. The experiments were performed four times, in duplicate.

\section{SDS-PAGE and western blotting}

Samples were incubated at $100{ }^{\circ} \mathrm{C}$ for $10 \mathrm{~min}$ in sample buffer containing $15 \mathrm{mM}$ Tris-HCl, pH 6.8, 0.5\% SDS, $2.5 \%$ glycerol, $25 \mathrm{mM}$ dithiothreitol and $0.05 \%$ bromophenol blue. SDS-PAGE was conducted on a Pharmacia Phast System (Pharmacia-LKB, Uppsala, Sweden) using 7.5\% polyacrylamide gels, according to the manufacturers protocol. The approximate concentration DMBT1 ${ }^{\mathrm{SAG}}$ loaded on SDS-PAGE was $2 \mu \mathrm{g}$.

Western blotting was performed as described before (Ligtenberg et al. 2001). Nitrocellulose membranes were incubated with mAb DMBT1h12 antibodies. Bound antibodies were detected with alkaline phosphataseconjugated to rabbit anti-mouse immunoglobulins (DAKO, Glostrup, Denmark) using 5-bromo-4-chloro-3indolyl-phosphate (X-P) and nitro blue tetrazolium chloride (NBT) (Boehringer Mannheim, Germany) as substrate.

\section{Statistical analysis}

The mean bacteria binding activity of the 6 and $8 \mathrm{~kb}$ variant was compared with Mann-Whitney U tests, using IBM SPSS Statistics for Windows version 20.0 (IBM Corp, Armonk NY. USA). $P$ values $<0.05$ were considered statistical significant.

\section{Results}

\section{Determination of interindividual polymorphism of DMBT1}

Some years ago, we discovered genetic polymorphism within DMBT1 (Mollenhauer et al. 2002a; Mollenhauer et al. 1999; Mollenhauer et al. 2002b) (Fig. 1). This lead us to hypothesize that this polymorphism results in a differential efficacy in mucosal protection. In order to answer this hypothesis, we first screened 200 persons for genetic DMBT1 polymorphism. We found two persons (donors A and C) that were homozygous for a small DMBT1 variant with 8 SRCR domains in the $\mathrm{SID} / \mathrm{SRCR}$ region (encoded by the $6 \mathrm{~kb} D M B T 1$ variant). Furthermore, we found two persons (donors B and D) that were homozygous for a large DMBT1 variant with 13 SRCR domains in the SID/SRCR region (encoded by the $8 \mathrm{~kb}$ DMBT1variant) (Fig. 1).

Now that DMBT1 polymorphism was found on a genetic level, we wanted to confirm these findings on the polypeptide level. For this, we collected DMBT1 ${ }^{\mathrm{SAG}}$ from the four donors and analyzed protein size by SDS-PAGE and subsequent Western analysis, using mAb DMBT1h12 for immunodetection. In SDS-PAGE DMBT1 ${ }^{\text {SAG }}$ of donors A and $\mathrm{C}$ migrated to a position corresponding with an apparent molecular mass of approximately $255 \mathrm{kDa}$. DMBT1 ${ }^{\mathrm{SAG}}$ of donors B and D migrated in SDS-PAGE to a position corresponding with an apparent molecular mass of approximately $340 \mathrm{kDa}$. These data agreed with the genetic analysis (Fig. 1), revealing that on the one hand donors $\mathrm{A}$ and $\mathrm{C}$ express the "short" DMBT1 ${ }^{\text {SAG }}$ of $255 \mathrm{kDa}$, which putatively contains 8 SRCR domains in the SID/SRCR region. On the other hand, donors B and D express the "long" DMBT1 1 SAG isoform, which putatively contains the SID/SRCR region with 13 SRCR domains (Figs. 1 and 2a). 


\section{a}

\begin{tabular}{cccccccccc}
0 & 5 & 10 & 15 & 20 & 25 & 30 & 35 & 40 & 45 \\
\hline & 1 & 1 & 1 & 1 & 1 & 1 & 1 & 1 \\
\hline
\end{tabular}

Scale in kb
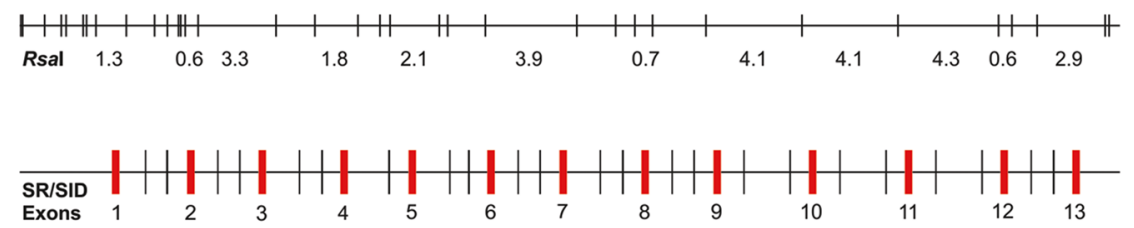

$8 \mathrm{~kb}$ variant

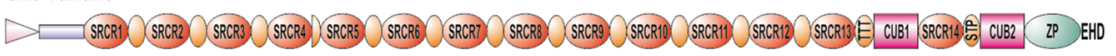

\section{$6 \mathrm{~kb}$ variant}

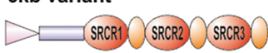

b

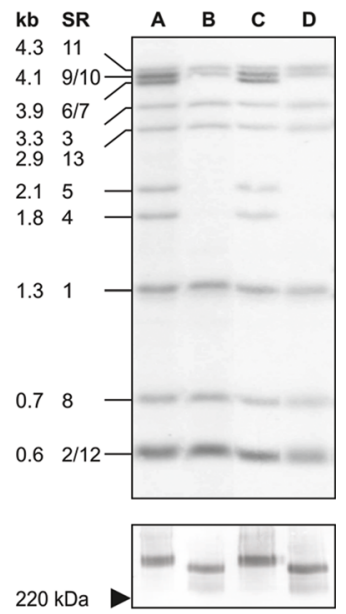

Fig. 1 DMBT1 polymorphism leads to different length DMBT1 polypeptides. a Schematical presentation of the exon-intron structure within the relevant region of $D M B T 1$ with resulting $R s a \mathrm{I}$ restriction fragment sizes depicted below. Gray boxes denote restriction fragments hybridizing with the probe $D M B T 1 / \mathrm{sr} 1 \mathrm{sid} 2$. SR exons coding for scavenger receptor cysteine-rich domains. The hypothetical configurations within the proteins are depicted below. In the carboxyterminal part of the protein resulting from the deleted allele, it cannot be discerned between a loss of either SR9, SR10, or SR11. Only one of the possibilities is shown. Pink triangle signal peptide, blue box motif without homology, $S R C R$ scavenger receptor cysteine-rich domain, CUB $\mathrm{C} 1 \mathrm{r} / \mathrm{C} 1 \mathrm{~s}-$ Uegf-Bmp1 domains, $Z P$ zona pellucida domain. $E H D$ Ebnerin-homologous domain, orange ovals SRCR interspersed domains (SIDs), TTT and STP are threonine and serine-threonineproline-rich domains, respectively. b Top panel Southern blot analysis of the DMBT1 genomic configuration in four individuals (A-D) selected from the panel. Band sizes and exons locating on the restriction fragments are depicted at the left. Bottom panel Western blot analysis of DMBT1 ${ }^{\mathrm{SAG}}$ protein sizes in the partially purified and concentration-adjusted saliva samples of the four probands. The arrowhead denotes the position of the $220-\mathrm{kDa}$ marker band. DMBT1 ${ }^{\text {SAG }}$ was collected from saliva donors that were homozygous for $D M B T 1 / 8 \mathrm{~kb}$ (donors A and C), homozygous for DMBT1/6 kb (donors B and D). Crude DMBT1 ${ }^{\mathrm{SAG}}$ from the four donors samples were separated on $7.5 \%$ polyacrylamide gels, transferred to nitrocellulose and immunoblotted with mAb DMBT1H12 . Lane 1 donor A, lane 2, donor B; lane 3, donor C; lane 4, donor D. DMBT1 ${ }^{\text {SAG }}$ of donors A and C migrated at a position corresponding to an apparent molecular mass of approximately $340 \mathrm{kDa}$. DMBT1 ${ }^{\text {SAG }}$ of donors $\mathrm{B}$ and $\mathrm{D}$ runs at a position corresponding to approximately $255 \mathrm{kDa}$

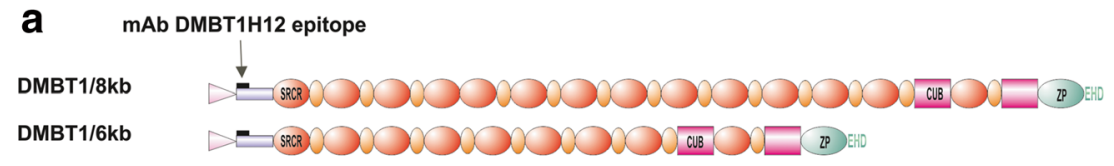

b

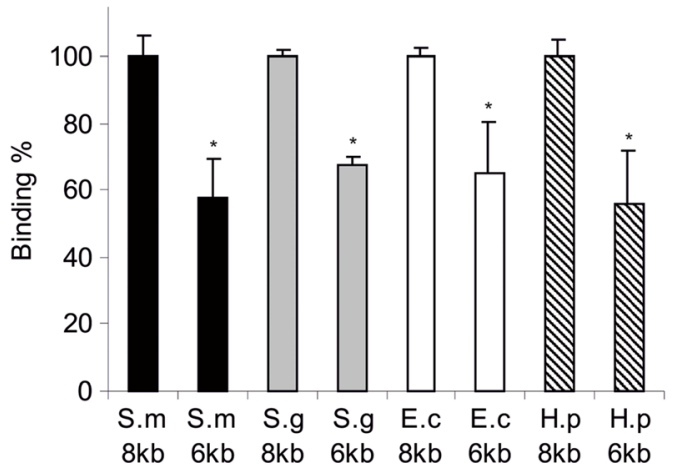

Fig. 2 Bacterial binding is dependent on DMBT1 polymorphism. a Domain structure of the DMBT1-variant expressed from the large $D M B T 1$ allele $(D M B T 1 / 8 \mathrm{~kb}, 13$ SRCR domains within the SRCR/SID region) and the small $D M B T 1$ allele (DMBT1/6 kb, 8 SRCR domains within the SRCR/SID region). Pink triangle leader peptide, blue box sequence contains unique epitope for mAb DMBT1H12, red ovals SRCR domains, orange ovals, SRCR interspersed domains (SIDs), purple boxes $\mathrm{C} 1 \mathrm{r} / \mathrm{C} 1 \mathrm{~s}-U$ egf-Bmp1 domains, green oval zona pellucida domain, EHD Ebnerin-Homologous Domain. b Bacterial binding to DMBT1/8 kb and DMBT1/6 kb (A) was semi-quantified using S. mutans (S.m), S. gordonii (S.g.), E. coli (E.c.), and H. pylori (H.p.). Relative to the wild type DMBT1 ${ }^{\mathrm{SAG}} / 8 \mathrm{~kb}$ we found, on a molecular base, a decrease in bacterial binding to $\mathrm{DMBT} 1^{\mathrm{SAG}} / 6 \mathrm{~kb}$ for all bacteria tested. Error bars represent the standard error of the mean (SEM), $P \leq 0.05$ 


\section{DMBT1 polymorphism leads to differential bacterial binding}

To examine whether this polymorphism affects biological relevant function of DMBT1 ${ }^{\mathrm{SAG}}$, we compared the bacteriabinding properties of two different genetic variants from donors $\mathrm{A}(8 \mathrm{~kb})$ and $\mathrm{B}(6 \mathrm{~kb})$. First, the DMBT1 ${ }^{\mathrm{SAG}}$ content of the various preparations was quantified in ELISA using mAbDMBT1h12. Then, each sample was diluted so that the preparations matched each other in epitope concentration, as was verified by western analysis using mAb DMBT1h12 (Fig. 1b). The solutions subsequently were used to coat microtiter plate wells. Equal coating densities of the different DMBT1 preparations were confirmed by ELISA.

The wells coated with DMBT $11^{\mathrm{SAG}}$ were incubated with various bacterial species, including S. mutans, S. gordonii, E. coli, and $H$. pylori for $1 \mathrm{~h}$. After washing and addition of the fluorogenic probe, the number of adhering cells was quantified by fluorescence (Fig. 2). The results indicated that wells coated with the short variant $\mathrm{DMBT} 1^{\mathrm{SAG}} 6 \mathrm{~kb}$ bound, on a molar base, significantly less bacteria, than those coated with the longvariant $\mathrm{DMBT1}{ }^{\mathrm{SAG}} 8 \mathrm{~kb}$. The relative difference in binding for the bacteria tested were $42.4 \%(+/-11.7)$ for $S$. mutans $(P=0.016), 32.5 \%(+/-2.7)$ for $S$. gordonii $(P=0.031)$, $44.3 \%(+/-15.5)$ for $E$. coli $(P=0.029)$ and $35.1 \%(+/-16.0)$ for H. pylori $(P=0.032)$ (Fig. 2b). No binding was observed on the BSA coated microplates (data not shown).

\section{Discussion}

In this study, we demonstrated that genetic polymorphism, i.e., a reduction of the tandem repeat of the SRCR domains and SIDs of DMBT1, results in a corresponding reduction of the protein size (Fig. 1 and 2a). In a previous study, using an ELISA based adherence assay, was shown that DMBT1 ${ }^{\text {SAG }}$ displays binding to a wide variety of bacteria. Using this assay, we quantified bacterial binding of DMBT1 variants isolated from donors with different genotypes. Based on the assumption that a single SRCR domain contains a single bacterial binding site, located in a putative cleft (Bikker et al. 2004; Bikker et al. 2002; Muller et al. 1999), 8 SRCR within the SRCR/SRCR region domains should theoretically contain $38 \%$ less binding capacity than 13 SRCR domains.

We observed that, compared to wild-type DMBT1 $(8 \mathrm{~kb}$, 13 SRCR domains in the SID/SRCR region), the short DMBT1variant $(6 \mathrm{~kb}, 8$ SRCR domains in the SID/SRCR region) displayed an about $30-45 \%$ reduced capacity to bind Gram-positive and Gram-negative bacteria in vitro. This suggests that genetic polymorphism of DMBT1 impairs its protective functions, as supported by complete inactivation in $D M B T 1$-knockout mice (Renner et al. 2007). Genetic polymorphism within $D M B T 1$ has been described extensively and appears to be exceptionally high (Mollenhauer et al. 2000; Mollenhauer et al. 1999; Polley et al. 2015). It has also been reported for other SRCR proteins as well, and seems to be an overall characteristic feature of members of the SRCR superfamily. Genetic polymorphism for SRCR proteins has been reported, e.g., for human CD5 (Padilla et al. 2000), human CD163 sponge Aggregation Receptor (Muller et al. 1999; Pancer 2000), and sheep T19 (Walker et al. 1994). Genetic polymorphism of $D M B T 1$ was suggested to be linked to functionality, i.e., bacterial binding and hydroxyapatite binding of the polypeptide of DMBT1 ${ }^{\mathrm{SAG}}$ (Bikker et al. 2013; Bikker et al. 2002). Copy number variants that bound strongly to S. mutans and less to hydroxyapatite seemed to be increased in agricultural populations compared to hunter-gatherer populations and ancient hominins (Polley et al. 2015). As S. mutans is the causative agent in dental caries; it was speculated that some kind of selection for caries resistance had occurred in agricultural populations. We show that deletion of the SRCR domains not only affects binding to S. mutans, but also to other bacteria. Selective pressure from other bacterial infections, which occur more frequently in agricultural populations, may have favored the selection of strong binding copy number variants.

It has to be noted that in this study crude preparations of $\mathrm{DMBT1}^{\mathrm{SAG}}$ were used for bacterial adhesion analysis.

Although, it cannot be excluded that a variety of proteins such as amylase, proline rich proteins, and s-IgA may have coprecipitated with $\mathrm{DMBT} 1^{\mathrm{SAG}}$; it appears that crude $\mathrm{DMBT} 1^{\mathrm{SAG}}$ shows representative bacteria binding characteristics. In line with earlier studies with purified DMBT1 ${ }^{\text {SAG }}$ and recombinant DMBT1, crude DMBT1 ${ }^{\mathrm{SAG}}$ preparations show comparable bacteria binding characteristics (Bikker et al. 2004; Bikker et al. 2002; End et al. 2009; End et al. 2005; Leito et al. 2008; Ligtenberg et al. 2004; Ligtenberg et al. 2001). And, as DMBT1 ${ }^{\mathrm{SAG}}$ is obtained directly from the parotid gland, the presence of bacteria-binding salivary mucins (MUC7) can be excluded (Veerman et al. 1996).

The present data suggest that the SRCR/SID region defines a complex multi-allele system that represents a possible basis for the variability in human susceptibility to infection as suggested in earlier papers (Mollenhauer et al. 2002a; von Deimling et al. 2000).

Acknowledgements This work was supported by the European Molecular Biology Organization (EMBO), grant ASTF 115-02, the Netherlands Organization for Scientific Research (NWO), grant ER 90184, the Deutsche Krebshilfe, grant no. 1835-Mo I, and the Wilhelm Sander-Stiftung, grant no. 99.018.2.

Open Access This article is distributed under the terms of the Creative Commons Attribution 4.0 International License (http:// creativecommons.org/licenses/by/4.0/), which permits unrestricted use, distribution, and reproduction in any medium, provided you give appropriate credit to the original author(s) and the source, provide a link to the Creative Commons license, and indicate if changes were made. 


\section{References}

Aruffo A, Bowen MA, Patel DD, Haynes BF, Starling GC, Gebe JA, Bajorath J (1997) CD6-ligand interactions: a paradigm for SRCR domain function? Immunol Today 18:498-504

Aruffo A, Melnick MB, Linsley PS, Seed B (1991) The lymphocyte glycoprotein CD6 contains a repeated domain structure characteristic of a new family of cell surface and secreted proteins. J Exp Med 174:949-952

Bikker FJ, Cukkemane N, Nazmi K, Veerman EC (2013) Identification of the hydroxyapatite-binding domain of salivary agglutinin. Eur J Oral Sci 121:7-12

Bikker FJ, Ligtenberg AJ, End C, Renner M, Blaich S, Lyer S, Wittig R, van't Hof W, Veerman EC, Nazmi K, de Blieck-Hogervorst JM, Kioschis P, Nieuw Amerongen AV, Poustka A, Mollenhauer J (2004) Bacteria binding by DMBT1/SAG/gp-340 is confined to the VEVLXXXXW motif in its scavenger receptor cysteine-rich domains. J Biol Chem 279:47699-47703

Bikker FJ, Ligtenberg AJ, Nazmi K, Veerman EC, van't Hof W, Bolscher JG, Poustka A, Nieuw Amerongen AV, Mollenhauer J (2002) Identification of the bacteria-binding peptide domain on salivary agglutinin (gp-340/DMBT1), a member of the scavenger receptor cysteine-rich superfamily. J Biol Chem 277:32109-32115

Boks MA, Gunput ST, Kosten I, Gibbs S, van Vliet SJ, Ligtenberg AJ, van Kooyk Y (2016) The human glycoprotein salivary agglutinin inhibits the interaction of DC-SIGN and langerin with oral microorganisms. J Innate Immun 8:350-361

Bork P, Beckmann G (1993) The CUB domain. A widespread module in developmentally regulated proteins. J Mol Biol 231:539-545

Brittan JL, Nobbs AH (2015) Group B Streptococcus pili mediate adherence to salivary glycoproteins. Microbes Infect 17:360-368

Elomaa O, Sankala M, Pikkarainen T, Bergmann U, Tuuttila A, Raatikainen-Ahokas A, Sariola H, Tryggvason K (1998) Structure of the human macrophage MARCO receptor and characterization of its bacteria-binding region. J Biol Chem 273:4530-4538

End C, Bikker F, Renner M, Bergmann G, Lyer S, Blaich S, Hudler M, Helmke B, Gassler N, Autschbach F, Ligtenberg AJ, Benner A, Holmskov U, Schirmacher P, Nieuw Amerongen AV, Rosenstiel P, Sina C, Franke A, Hafner M, Kioschis P, Schreiber S, Poustka A, Mollenhauer J (2009) DMBT1 functions as pattern-recognition molecule for poly-sulfated and poly-phosphorylated ligands. Eur J Immunol 39:833-842

End C, Lyer S, Renner M, Stahl C, Ditzer J, Holloschi A, Kuhn HM, Flammann HT, Poustka A, Hafner M, Mollenhauer J, Kioschis P (2005) Generation of a vector system facilitating cloning of DMBT1 variants and recombinant expression of functional full-length DMBT1. Protein Expr Purif 41:275-286

Freeman M, Ashkenas J, Rees DJ, Kingsley DM, Copeland NG, Jenkins NA, Krieger M (1990) An ancient, highly conserved family of cysteine-rich protein domains revealed by cloning type I and type II murine macrophage scavenger receptors. Proc Natl Acad Sci U S A $87: 8810-8814$

Gough PJ, Gordon S (2000) The role of scavenger receptors in the innate immune system. Microbes Infect 2:305-311

Gunput ST, Wouters D, Nazmi K, Cukkemane N, Brouwer M, Veerman EC, Ligtenberg AJ (2016) Salivary agglutinin is the major component in human saliva that modulates the lectin pathway of the complement system. Innate Immun 22:257-65

Hartshorn KL, White MR, Mogues T, Ligtenberg T, Crouch E, Holmskov U (2003) Lung and salivary scavenger receptor glycoprotein-340 contribute to the host defense against influenza A viruses. Am J Physiol Lung Cell Mol Physiol 285:L1066-L1076

Hohenester E, Sasaki T, Timpl R (1999) Crystal structure of a scavenger receptor cysteine-rich domain sheds light on an ancient superfamily. Nat Struct Biol 6:228-232
Holmskov U, Lawson P, Teisner B, Tornoe I, Willis AC, Morgan C, Koch C, Reid KB (1997) Isolation and characterization of a new member of the scavenger receptor superfamily, glycoprotein-340 (gp-340), as a lung surfactant protein-D binding molecule. J Biol Chem 272: 13743-13749

Holmskov U, Mollenhauer J, Madsen J, Vitved L, Gronlund J, Tornoe I, Kliem A, Reid KB, Poustka A, Skjodt K (1999) Cloning of gp-340, a putative opsonin receptor for lung surfactant protein D. Proc Natl Acad Sci U S A 96:10794-10799

Jovine L, Qi H, Williams Z, Litscher E, Wassarman PM (2002) The ZP domain is a conserved module for polymerization of extracellular proteins. Nat Cell Biol 4:457-461

Kohlgraf KG, Gawron AJ, Higashi M, Meza JL, Burdick MD, Kitajima S, Kelly DL, Caffrey TC, Hollingsworth MA (2003) Contribution of the MUC1 tandem repeat and cytoplasmic tail to invasive and metastatic properties of a pancreatic cancer cell line. Cancer Res 63: 5011-5020

Kukita K, Kawada-Matsuo M, Oho T, Nagatomo M, Oogai Y, Hashimoto M, Suda Y, Tanaka T, Komatsuzawa H (2013) Staphylococcus aureus SasA is responsible for binding to the salivary agglutinin gp340, derived from human saliva. Infect Immun 81:1870-1879

Leito JT, Ligtenberg AJ, Nazmi K, de Blieck-Hogervorst JM, Veerman EC, Nieuw Amerongen AV (2008) A common binding motif for various bacteria of the bacteria-binding peptide SRCRP2 of DMBT1/gp-340/salivary agglutinin. Biol Chem 389:1193-1200

Ligtenberg AJ, Bikker FJ, De Blieck-Hogervorst JM, Veerman EC, Nieuw Amerongen AV (2004) Binding of salivary agglutinin to IgA. Biochem J 383:159-164

Ligtenberg TJ, Bikker FJ, Groenink J, Tornoe I, Leth-Larsen R, Veerman EC, Nieuw Amerongen AV, Holmskov U (2001) Human salivary agglutinin binds to lung surfactant protein-D and is identical with scavenger receptor protein gp-340. Biochem J 359:243-248

Madsen J, Mollenhauer J, Holmskov U (2010) Review: Gp-340/DMBT1 in mucosal innate immunity. Innate Immun 16:160-167

Mollenhauer J, Helmke B, Muller H, Kollender G, Lyer S, Diedrichs L, Holmskov U, Ligtenberg T, Herbertz S, Krebs I, Wiemann S, Madsen J, Bikker F, Schmitt L, Otto HF, Poustka A (2002a) Sequential changes of the DMBT1 expression and location in normal lung tissue and lung carcinomas. Genes Chromosomes Cancer 35:164-169

Mollenhauer J, Herbertz S, Helmke B, Kollender G, Krebs I, Madsen J, Holmskov U, Sorger K, Schmitt L, Wiemann S, Otto HF, Grone HJ, Poustka A (2001) Deleted in malignant brain tumors 1 is a versatile mucin-like molecule likely to play a differential role in digestive tract cancer. Cancer Res 61:8880-8886

Mollenhauer J, Herbertz S, Holmskov U, Tolnay M, Krebs I, Merlo A, Schroder HD, Maier D, Breitling F, Wiemann S, Grone HJ, Poustka A (2000) DMBT1 encodes a protein involved in the immune defense and in epithelial differentiation and is highly unstable in cancer. Cancer Res 60:1704-1710

Mollenhauer J, Holmskov U, Wiemann S, Krebs I, Herbertz S, Madsen J, Kioschis P, Coy JF, Poustka A (1999) The genomic structure of the DMBT1 gene: evidence for a region with susceptibility to genomic instability. Oncogene 18:6233-6240

Mollenhauer J, Muller H, Kollender G, Lyer S, Diedrichs L, Helmke B, Holmskov U, Ligtenberg T, Herbertz S, Krebs I, Madsen J, Bikker F, Schmitt L, Wiemann S, Scheurlen W, Otto HF, von Deimling A, Poustka A (2002b) The SRCR/SID region of DMBT1 defines a complex multi-allele system representing the major basis for its variability in cancer. Genes Chromosomes Cancer 35:242-255

Mollenhauer J, Wiemann S, Scheurlen W, Korn B, Hayashi Y, Wilgenbus KK, von Deimling A, Poustka A (1997) DMBT1, a new member of the SRCR superfamily, on chromosome 10q25.3-26.1 is deleted in malignant brain tumours. Nat Genet 17:32-39

Muller WE, Koziol C, Muller IM, Wiens M (1999) Towards an understanding of the molecular basis of immune responses in sponges: the 
marine demosponge Geodia cydonium as a model. Microsc Res Tech 44:219-236

Padilla O, Calvo J, Vila JM, Arman M, Gimferrer I, Places L, Arias MT, Pujana MA, Vives J, Lozano F (2000) Genomic organization of the human CD5 gene. Immunogenetics 51:993-1001

Pahler S, Blumbach B, Muller I, Muller WE (1998) Putative multiadhesive protein from the marine sponge Geodia cydonium: cloning of the cDNA encoding a fibronectin-, an SRCR-, and a complement control protein module. J Exp Zool 282:332-343

Pancer Z (2000) Dynamic expression of multiple scavenger receptor cysteine-rich genes in coelomocytes of the purple sea urchin. Proc Natl Acad Sci U S A 97:13156-13161

Polley S, Louzada S, Forni D, Sironi M, Balaskas T, Hains DS, Yang F, Hollox EJ (2015) Evolution of the rapidly mutating human salivary agglutinin gene (DMBT1) and population subsistence strategy. Proc Natl Acad Sci U S A 112:5105-5110

Prakobphol A, Xu F, Hoang VM, Larsson T, Bergstrom J, Johansson I, Frangsmyr L, Holmskov U, Leffler H, Nilsson C, Boren T, Wright JR, Stromberg N, Fisher SJ (2000) Salivary agglutinin, which binds Streptococcus mutans and Helicobacter pylori, is the lung scavenger receptor cysteine-rich protein gp-340. J Biol Chem 275:39860-39866

Reichhardt MP, Jarva H, de Been M, Rodriguez JM, Jimenez Quintana E, Loimaranta V, de Vos WM, Meri S (2014) The salivary scavenger and agglutinin in early life: diverse roles in amniotic fluid and in the infant intestine. J Immunol 193:5240-5248

Renner M, Bergmann G, Krebs I, End C, Lyer S, Hilberg F, Helmke B, Gassler N, Autschbach F, Bikker F, Strobel-Freidekind O, GronertSum S, Benner A, Blaich S, Wittig R, Hudler M, Ligtenberg AJ, Madsen J, Holmskov U, Annese V, Latiano A, Schirmacher P, Amerongen AV, D'Amato M, Kioschis P, Hafner M, Poustka A, Mollenhauer J (2007) DMBT1 confers mucosal protection in vivo and a deletion variant is associated with Crohn's disease. Gastroenterology 133:1499-1509

Resnick D, Pearson A, Krieger M (1994) The SRCR superfamily: a family reminiscent of the Ig superfamily. Trends Biochem Sci 19:5-8
Romero A, Romao MJ, Varela PF, Kolln I, Dias JM, Carvalho AL, Sanz L, Topfer-Petersen E, Calvete JJ (1997) The crystal structures of two spermadhesins reveal the CUB domain fold. Nat Struct Biol 4:783-788

Sinowatz F, Kolle S, Topfer-Petersen E (2001) Biosynthesis and expression of zona pellucida glycoproteins in mammals. Cells Tissues Organs 168:24-35

Sonesson M, Ericson D, Kinnby B, Wickstrom C (2011) Glycoprotein 340 and sialic acid in minor-gland and whole saliva of children, adolescents, and adults. Eur J Oral Sci 119:435-440

Stoddard E, Cannon G, Ni H, Kariko K, Capodici J, Malamud D, Weissman D (2007) gp340 expressed on human genital epithelia binds HIV-1 envelope protein and facilitates viral transmission. J Immunol 179:3126-3132

Thornton DJ, Davies JR, Kirkham S, Gautrey A, Khan N, Richardson PS, Sheehan JK (2001) Identification of a nonmucin glycoprotein (gp340) from a purified respiratory mucin preparation: evidence for an association involving the MUC5B mucin. Glycobiology 11:969977

Tino MJ, Wright JR (1999) Glycoprotein-340 binds surfactant protein-A (SP-A) and stimulates alveolar macrophage migration in an SP-Aindependent manner. Am J Respir Cell Mol Biol 20:759-768

Veerman EC, van den Keybus PA, Vissink A, Nieuw Amerongen AV (1996) Human glandular salivas: their separate collection and analysis. Eur J Oral Sci 104:346-352

von Deimling A, Fimmers R, Schmidt MC, Bender B, Fassbender F, Nagel J, Jahnke R, Kaskel P, Duerr EM, Koopmann J, Maintz D, Steinbeck S, Wick W, Platten M, Muller DJ, Przkora R, Waha A, Blumcke B, Wellenreuther R, Meyer-Puttlitz B, Schmidt O, Mollenhauer J, Poustka A, Stangl AP, Lenartz D, von Ammon K (2000) Comprehensive allelotype and genetic analysis of $466 \mathrm{hu}-$ man nervous system tumors. J Neuropathol Exp Neurol 59:544-558

Walker ID, Glew MD, O'Keeffe MA, Metcalfe SA, Clevers HC, Wijngaard PL, Adams TE, Hein WR (1994) A novel multi-gene family of sheep gamma delta $\mathrm{T}$ cells. Immunology 83:517-523 